\title{
TEORIA I PRAKTYKA. WERYFIKACJA UMIEJĘTNOŚCI DOWÓDCZYCH ABSOLWENTÓW POLSKIEJ SZKOLY WOJSKOWEJ W GENUI I CUNEO (1861-1862) PODCZAS POWSTANIA STYCZNIOWEGO (1863-1864)
}

10 marca 2012 roku w piemonckiej miejscowości Cuneo na budynku dawnego Kolegium Świętego Franciszka uroczyście odsłonięto tablicę upamiętniającą działalność Polskiej Szkoły Wojskowej, założonej w Genui (1861) i w 1862 r. przeniesionej do podalpejskiego miasteczka. Wypowiadali się burmistrz Cuneo Alberto Valmaggia, nuncjusz apostolski w Polsce, urodzony w Cuneo arcybiskup Celestino Migliore, ambasador RP w Watykanie Hanna Suchocka, konsul generalny RP w Mediolanie Krzysztof Strzałka i sekretarz Rady Ochrony Pamięci Walk i Męczeństwa (fundatora tablicy) Andrzej Krzysztof Kunert ${ }^{1}$.

W tłumaczeniu na język polski napis na tablicy brzmi:

\author{
OD 26 KWIETNIA DO 30 LIPCA 1862 ROKU \\ MURY KOLEGIUM ŚWIĘTEGO FRANCISZKA GOŚCIŁY \\ EMIGRANTÓW Z POLSKIEJ SZKOŁY WOJSKOWEJ. \\ CUNEO PRZYJĘŁO ICH SZLACHETNIE I PO BRATERSKU \\ PAMIĘTAJĄC WALKĘ POLAKÓW U BOKU WŁOCHÓW \\ O WOLNOŚĆ I ZJEDNOCZENIE WŁOCH. \\ W 150 ROCZNICĘ ZJEDNOCZENIA MIESZKAŃCY I POLACY \\ PAMIĘTAJĄ \\ AD 2012
}

Ponieważ o Szkole Genueńsko-Cuneańskiej wzmiankuje się często jako o jednej z kilku kuźni kadry dowódczej polskiego powstania narodowego, warto przyjrzeć się bliżej praktycznemu zastosowaniu nabytej w niej wiedzy o charakterze militarnym. Analiza dowódczej kariery kilkunastu spośród stu kilkudziesięciu absolwentów emigracyjnej placówki umożliwi odpowiedź na pytanie, jak jej wychowankowie prezentowali się na tle innych kadrowych grup proweniencyjnych, takich jak byli oficerowie armii państw zaborczych, weterani powstania 1830-1831 r., uczestnicy walk rewolucyjnych i wyzwoleńczych 1831-1863, czy też cywile.

Portal Rady Ochrony Pamięci Miejsc i Męczeństwa ROPWiM, 10.03.2012. 


\section{O Szkole}

Późną jesienią 1861 r. paryskie Towarzystwo Młodzieży Polskiej, nastawione na wywołanie zbrojnego powstania na ziemiach zaboru rosyjskiego zdecydowało się zapewnić mu przeszkoloną kadrę oficerską rekrutującą się z reprezentacji młodego pokolenia pozostającej na wychodźstwie i regularnie zasilanej z kraju. Potencjalny wódz naczelny zrywu niepodległościowego, bożyszcze młodocianych patriotów, gen. Ludwik Mierosławski miał objąć kierownictwo Polskiej Szkoły Wojskowej, którą ze względu na niechęć władz II Cesarstwa Francuskiego zamierzano utworzyć na ziemi włoskiej². Powstały w lipcu 1861 r. Polsko-Włoski Komitet w Turynie (Camitato di sussidio agli esuli Polacchci), a także osobista interwencja Giuseppe Garibaldiego przyczyniły się do uzyskania zgody rządu Zjednoczonego Królestwa Włoch na powołanie PSW w Genui (k. IX/1 X 1861) z siedzibą w dwupiętrowym, murowanym budynku zwanym Casa Bianchetti. Komitet Opiekuńczy Szkoły obejmował takie nazwiska, jak gen. ks. Napoleon Hieronim Bonaparte -Plon-Plon, gen. Hieronim Bixio, dr Ignazio Occhipinti, ks. Marceli Lubomirski i deputowany Lorenzo Valerio ${ }^{3}$. Władze darowały na remont, adaptację oraz wstępne wyposażenie 100 tys. franków, Bohater Dwóch Kontynentów uzyskał dla placówki plac ćwiczeniowy, karabiny i wierzchowce, armaty, 100 czerwonych koszul i tyleż koców ${ }^{4}$. Stosunkowo szybko skoszarowano patriotycznie usposobioną młodzież, objęto ją formą dyscypliny wojskowej, odziano w popielate czamary i czerwone, obszyte białym barankiem rogatywki ${ }^{5}$.

Kilkumiesięczne przeszkolenie służyć miało opanowaniu przez podchorążych zasad dowodzenia bojowego batalionem wraz z podstawami wiedzy instruktorskiej, przewidzianej dla potencjalnego legionu polskiego, bądź powstańczych sił zbrojnych. Szkoła dysponowała dość liczną i dobrze przygotowaną kadrą pedagogiczną ${ }^{6}$. Dbano o moralne i patriotyczne wychowanie kursantów, wymagano od nich wierności idei sprawy narodowej i sprawiedliwości społecznej. Pomagały w tym stanowiąca formę regulaminu tzw. Ustawa obowiązująca

\footnotetext{
2 Księga Pamiątkowa 1830-29 XI-1930. Szkice z dziejów szkót piechoty polskiej, Ostrów-Komorowo 1930, s.212230; A. Knot, Dzieje szkolnictwa wojskowego w Polsce, Lwów 1938, s.98-102; E. Halicz, Polska Szkoła Wojskowa w Genui i Cuneo (1861-1862), „Biuletyn Wojskowej Akademii Politycznej”, Seria Historyczna nr 2, rok V, nr 3 (16), Warszawa 1959, s.110-128; W.Karbowski, Polska Szkoła Wojskowa we Włoszech (1861-1862), „Studia i Materiały do Historii Wojskowosci", t.VIII, cz.2, Warszawa 1962, s.21 i n; J.Moliński, Przygotowania do wybuchu powstania styczniowego, „SiMdHW”, t.VIII, cz.2, s.95-97; J. Cytowski, Z dziejów polskiego szkolnictwa wojskowego (Polskie szkoty i kursy wojskowe w latach 1832-1918), „Zeszyty Naukowe WAP”, nr 4 (137), Warszawa 1988, s.171-174; A. Cwer, Polska wojskowa myśl wychowawcza w latach 1794-1864, Kielce 2010, s.205-210.

3 J. Białynia-Chołodecki, Polska Szkoła Wojskowa. Księga Pamiątkowa w 40 rocznicę powstania 1863-4, Lwów 1904, s.19; Zagłoba, Polska Szkoła Wojskowa we Włoszech, „Polska Zbrojna” nr 23 z 24 I 1923; K.Morawski, Polacy $i$ sprawa polska $w$ dziejach Italii $w$ latach 1830-1866, Rozprawy historyczne Towarzystwa Naukowego Warszawskiego, t. XVIII, z. 1, Warszawa 1937, s.156; J. Chodynicki, Szkoła w Cuneo, „Ateneum Wileńskie”, 1928, z.5,s.193; E. Halicz, Polska Szkoła Wojskowa, s.115; W. Mazurkiewicz, Emigracja polska w 1862 r. Szkoła Genueńska. Zjednoczenie, Paryż 1862, s.122-123; Zeznanie Władysława Daniłowskiego przed carska komisją śledcza w: Zeznania sledcze o powstaniu styczniowym, Wrocław 1956, s.98;

$4 \quad$ Z pamiętnika Romana Rogińskiego 1859-1863, Kraków 1898, s.17; A. Lewak, Polska korespondencja Józefa Garibaldiego, Kraków 1932, s.65.

5 A.Lewak, Czasy Wielkiej Emigracji, Warszawa 1930, s.304; A. Knot, Dzieje szkolnictwa wojskowego w Polsce, s.99; W. Karbowski, Polska Szkoła Wojskowa, s.28.

6 A. Knot, Dzieje szkolnictwa wojskowego, s.56; E.Halicz, Polska Szkoła Wojskowa, s. 115; W. Karbowski, Polska Szkoła Wojskowa, s.28, 55.
} 
uczniów i instruktorów Szkoły Wojskowej Polskiej w Włoszech, samorząd uczniowski zwany Towarzystwem Młodzieży, organ prasowy „Głos z Paryża i Genui”.

Po wewnętrznym przesileniu zastąpił Mierosławskiego na stanowisku dyrektorskim gen. Józef Wysocki (27 III 1862), bezpośrednim komendantem został płk Aleksander Fijałkowski, dowódca legii polskiej we Włoszech z 1849 r., a dyrektorem nauk płk Aleksander Waligórski ${ }^{8}$. W programie składającej się z wydziałów piechoty, kawalerii i artylerii szkoły przewidziano następujące zajęcia: teoria i praktyczna musztra piechoty i jazdy, teoria i działoczyn artylerii, nauka wyrobu prochu i amunicji, nauka musztry kosynierskiej i tyralierskiej; matematyka, strategia, taktyka i historia wojen; fortyfikacja polowa, geografia wojskowa i kartografia ziem polskich, geometria i pirotechnika. Zadbano ponadto o gimnastykę i zajęcia sportowe. $\mathrm{Na}$ terenie szkoły funkcjonowała biblioteka obejmująca księgozbiór z podręczników, regulaminów i klasycznych publikacji o tematyce militarnej.

Od schyłku kwietnia 1862 r. szkoła funkcjonować zaczęła w malowniczo zlokalizowanym podgórskim miasteczku Cuneo ${ }^{9}$. Umieszczono ją w wyremontowanym uprzednio, opuszczonym, acz obszernym ${ }^{10}$ klasztorze pofranciszkańskim i wyposażono na życzenie Garibaldiego w 20 koni, 6 armat i zapas ręcznego uzbrojenia. To tutaj dokonano zmiany uczniowskiego umundurowania na wzór polskich legionistów Wiosny Ludów na Węgrzech (ich ówczesnym wodzem był Józef Wysocki): granatowe kurtki z amarantowymi wypustkami, latem -białe kurtki i czerwone rogatywki. Przyjęty kurs nauczania na podoficera przewidywany był na 3 miesiące, na oficera zaś na minimum pół roku, przy czym po przeszkoleniu przewidywano egzamin komisyjny.

Koniunktura sprzyjająca istnieniu szkoły szybko się skończyła. ${ }^{11}$ Istnienie pozbawionej podstaw prawnej egzystencji placówki stanowiło dla rządu imperium carskiego wytrwale domagającego się jej likwidacji prowokację, będąc instrumentem presji dyplomatycznej Turynu na niechętny do uznania młodej państwowości Petersburg. ${ }^{12}$ Słuchaczy i absolwentów polskiego zakładu uważano za potencjalnych agentów politycznych wzniecających dążenia niepodległościowe. Zabiegi dyplomatyczne w celu likwidacji podobnych ośrodków w zachodniej Europie, ze względu na uosabianą przez prośby i naciski ingerencję w problematykę wewnętrzną Francji, Anglii i Włoch nazywane były delikatną materią. Popularność i sława placówki w kraju i za granicą stanowiła ujmę dla prestiżu caratu, a także inspirowała

\footnotetext{
E. Halicz, Polska Szkoła Wojskowa, załącznik nr 1, s.129-131; tekst w „Przeglądzie Rzeczy Polskich” nr 6, 1862.

8 E. Halicz, Polska Szkoła Wojskowa,s.122; W.Karbowski, Polska Szkoła Wojskowa, s.54-55; W.Mickiewicz, Pamiętniki, t.II, Kraków 1926, s.205-220; Z pamiętnika Romana, s.25-26.

9 E. Halicz, Polska Szkoła Wojskowa., s.123; W.Karbowski, Polska Szkoła Wojskowa, s.56; „Przegląd Rzeczy Polskich”, 16 V 1862-art. Polska szkoła wojskowa w Cuneo; Z pamiętnika Romana, s.28-29.

10 J. Zlasnowski, Wspomnienia ze szkoły podchorążych we Włoszech, ,Tygodnik Ilustrowany”, nr 4, 1917.

11 J. Chodynicki, Szkoła w Cuneo, s.203-205; E. Halicz, Polska Szkoła Wojskowa., s.126; „Dziennik Poznański” 1862, nr 159; „Przegląd Rzeczy Polskich” 1862, nr 7; „Głos z Paryża i Genui”, 1862, nr 5 z 10 VII; por. B.Czart., rkps 3743, k.537-538 - listy Fryderyka Wilhelma IV do posła pruskiego w Bolonii Franciszka Lucchesiniego dotycząca wsparcia Rosji w zabiegach o zamknięcie szkoły cuneańskiej, która „szkoli przyszłych konspiratorów, wywrotowców, ludzi zdolnych do walki partyzanckiej na ziemiach u naszych przyjaciół Rosjan- z 14 V i 22 V 1862; W.Mickiewicz, Emigracja polska 1860-1890, Kraków 1908, s.18-19.

12 W.Karbowski, Polska Szkoła Wojskowa, s.22, 28; Zob. artykuły w „Dzienniku Poznańskim” 1862, nr 159; „Przeglądzie Rzeczy Polskich” 1862 nr 6 i 7; „Głosie Paryża i Genui” 1861 nr 2 z 29 XI; Materiały po śp. Władysławie Milowiczu, Wydawnictwo materiałów do historii powstania 1863-1864, Lwów 1888, t.IV, s.48.
} 
organizację narodową w kraju do rozbudzania insurekcyjnych nastrojów ${ }^{13}$. Ze względu na polityczny nacisk ambasadorów Rosji i Prus, król Wiktor Emanuel wydał premierowi Urbanowi Ratazziemu polecenie zawieszenia, a następnie zamknięcia szkoły (26 czerwca). Z końcem lipca 1862 r. Polacy opuścili miasteczko.

Na temat uczniów podchorążówki emigracyjnej warto przytoczyć poglądy trzech uczestników niepodległościowego zrywu, a jednocześnie autorów prac nt. powstania styczniowego $^{14}$. Reprezentujący umiarkowane, centrowe poglądy Agaton Giller pisał: Młodzież nasza w krótkim czasie trwania tej szkoly, zajęta więcej niż nauka-intrygami, partiami i sporami (....) wyniosła z niej zarozumiatość i dziwaczne pretensje. Wielu zdawało się, że nabyli tam kwalifikacji dostatecznych na wodza i w powstaniu chcieli z tego tytulu nie stużyć, lecz przewodzić. Przynosili z soba (...) wyciagnięte z broszur starej emigracji usposobienie anarchiczne, nieufność do doświadczenia i wieku, pomiatanie zastugi, niecierpliwość oraz zuchwalstwo inicjatywy najszaleńczej, bez poczucia odpowiedzialnosci i żalu za klęski, jakie ich nieumiejętnosć i pycha sprowadzić musiały. Konserwatywny Walery Przyborowski konkludował: Oni to parli do szybkiego, natychmiastowego powstania, oni snuli najszaleńsze projekty, których wykonać nigdy nie umieli i nie byli zdolni do ich wykonania. Oprócz paru światlejszych postaci, które umrzeć przynajmniej umiały heroicznie, reszta była ludźmi lekkomyślnymi i nieudolnymi do najwyższego stopnia. „Czerwony” Władysław Milowicz twierdził natomiast: Wszyscy oni wzięli nastepnie czynny udziat w powstaniu i oddali wielkie ustugi, a wielu spomiędzy nich należało potem do rzędu najdzielniejszych dowódców partyzanckich oddziałów (....). Jak było faktycznie? Pomoże w tym analiza konkretnych przykładów.

\section{Próba klasyfikacji komendantów przeszkolonych w wychodźczej podchorążówce}

Uwzględniając kryteria: rozmiarów oddziału (co najmniej 100 podwładnych) oraz samodzielności dowodzenia (minimum w 1 starciu bojowym) udało się ustalić, iż na 237 wyselekcjonowanych postaci insurekcyjnych dowódców 1863-1864 r. 15 było wychowankami Polskiej Szkoły Wojskowej we Włoszech: ${ }^{15}$ Wacław Karol Broniewski, Teodor Cieszkowski, Leopold Czapiński, Faustyn Gryliński, Władysław Jabłonowski, Teofil Jurkowski, Bolesław Kołyszko, Aleksander Littich, Anastazy Mossakowski, Józef Oksiński, Roman Rogiński, Robert Skowroński, Paweł Suzin, Józef Tłuchowski i Feliks Wysłouch

\section{Elita dowódeza}

Roman Rogiński otwiera poczet najznakomitszych wychowanków placówki genueńsko-cuneańskiej. Opracowanie koncepcji napadu na powiatowy garnizon w Białej na Podlasiu w Noc Styczniową potwierdzało wysoką ocenę ze strony władz powstańczych,

\footnotetext{
13 W.Przyborowski, Historia dwóch lat 1861-1862, t.V, Kraków 1892, s.253; Z papierów po śp.Władysławie Milowiczu, Wydawnictwo materiałów, t.IV, s.49; „Przegląd Rzeczy Polskich” 1862, 30 VI; „Głos z Paryża i Genui”, 1862, nr 5 z 10 VII; „Dziennik Poznański” 1862, nr 137 z 17 V.

14 A. Giller, Historia powstania narodu polskiego w latach 1861-1864, Paryż 1868; t.II, s.313; W. Przyborowski, Historia, t.V, s.255; Z papierów po śp. W.Milowiczu, t.IV, s.49; Ci z Genui w powstaniu, „Dziennik Poznański” 1863, nr; Szkoła Polska w Genui i Cuneo, „Rzeczypospolita” 1913 nr 108.

15 Imienny wykaz wychowanków Polskiej Szkoły Wojskowej z uzupełnieniami Aleksandra Zdanowskiego podaje 205 nazwisk (w: J.Białynia-Chołodecki, Księga pamiątkowa -w 40 rocznicę powstania 1863-1864, Lwów 1904, s.20-23; A. Sujkowski, Emigracja i powstanie styczniowe (1862-1865) -w: Księga Pamiatkowa Szkoty Podchorażych Piechoty, Ostrów Mazowiecka 1930, s. 222-223, W.Karbowski, Polska Szkoła Wojskowa we Włoszech, s.7277-uzupełnienie z anonimowej pracy Szkoła Wojskowa Polska w Genui i Cuneo, ,Rzeczpospolita” nr 108 z 1913, s.260 i A. Sujkowski, op.cit)
} 
choć nie potwierdzoną stopniem wojskowym. O tym, jak Rogiński był zdeterminowany do działania, świadczyło wkroczenie przezeń wraz z 80 ochotnikami do Białej, lecz wobec liczebnej przewagi nieprzyjaciela (ok. 600 żołnierzy pod komendą gen.-mjr. Mamajewa, w baterii artylerii konnej, rocie piechoty, sotni kozaków, komendzie inwalidów), a także zwątpienia miejscowych konspiratorów, po drobnej utarczce z kozakami opuścił miasto. ${ }^{16}$ W ciągu kilku najbliższych dni młodociany naczelnik wojskowy pow. bialskiego wykazał zmysł organizacyjny i dojrzałość, organizując złożony z podstawowych rodzajów broni pułk powstańczy. Pierwsza walna bitwa stanowiła pokaz jego dowódczych zdolności (1 II 1863, Białka) ${ }^{17}$. Po rozpoznaniu terenu i analizie sił (ok. tysiąc powstańców miało przeciwko sobie - batalion pskowskiego pp, 2 roty strzeleckie rewelskiego pp, 15 kozaków, oddział techniczny, tj. ok. 1300 zmęczonych i zdezorientowanych Rosjan, przeważających w piechocie, artylerii oraz wyszkoleniu) podjął z pomocą doświadczonego szefa sztabu decyzję nocnego, zaskakującego uderzenia na nieprzyjacielski obóz. Zastosował element zmylenia, podejmując zamysł odcięcia przeciwnika od sił osłonowych oraz rozbicia. Umiejętnie użył konnego odwodu, wobec fiaska szturmu kosynierów na armaty, dla zapobieżenia załamaniu powstańczych szeregów zaordynował uporządkowany odwrót. Jedyna we wczesnym okresie powstania zbrojna przeprawa rzeczna po opuszczeniu zajętej stolicy powiatu (4 II, Niemirów nad Bugiem) stanowiła przykład manewru kolumny marszowej uchodzącej przed ppłk. Wimbergiem (400 piechurów, 50 kozaków, 1 działo). ${ }^{18}$

Zaangażowanie Rogińskiego w batalię zamykającą etap inicjatywy militarnej podlaskich insurgentów wskazuje, iż nie brakowało mu typowych dla dowódców 1863 r. cech charakteru (7 II, Siemiatycze ${ }^{19}$ ) Na sugestię wsparcia ze strony Władysława Cichorskiego- Zameczka podesłał mu oddziałową jazdę, jednak przybywszy z całością sił nie potrafił podporządkować się insurekcyjnemu wojewodzie Walentemu Lewandowskiemu formalnie dowodzącemu 4,3-tysięcznym zgrupowaniem, po czym spóźnił się z obsadą wyznaczonego odcinka obrony,

16 S. Gesket, Voennyje dejstvija w Carstve Polskim v 1863 godu. Nacalo vozstanija (I-1 pot.III), red.A. Puzyrewski, Varsava 1894, s.153-154; W. Przyborowski, Dzieje 1863 r., t.I, Kraków 1897, s.94; S. Zieliński, Bitwy i potyczki 1863-1864, Rapperswil 1913, s.56; S.Płoski, Działania Rogińskiego w powstaniu styczniowym, „Przegląd Historyczno-Wojskowy”, 1938, t.X, z.1, s.1-28; J. Tomczyk, Organizacja cywilno-wojskowa powstania styczniowego w Lubelskiem i na Podlasiu, „Roczniki Lubelskie”, t.6:1963, s.38; S. Góra, Partyzantka na Podlasiu 1863-1864, Warszawa 1976, s.55-56; „Wiadomosci z pola bitwy”, 1863 nr; „Czas” 1863 nr 29; „Dziennik Powszechny” 1863, nr 20; W. Lewandowski, Pamiętniki, s.; R. Rogiński, Zeznania w: Tenże, Zeznania i wspomnienia, opr. S. Kieniewicz, Warszawa 1983, s.49-50.

17 W. Przyborowski, Dzieje 1863 r., t.I, s.171; S. Zieliński, Bitwy, s.57-58; S. Płoski, Działania Rogińskiego, s.11-12; S. Góra, Partyzantka na Podlasiu, s.75-79; Urzędowy wykaz, s.279; „Wiadomosci z pola bitwy” 1863, nr 3; „Czas” 1863, nr 31, 32, 37, 38, 48; „Dziennik Powszechny” 1863, nr 27, 36; „Nadwiślanin”, 1863, nr 17; R. Rogiński, Zeznania, s.56-58.

18 M.I. Cyłow, Sbornik raporiażenij M.N. Murawiewa po usmirieniju polskogo miatieża w Siwero-Zapdnych gubiernijach 1863-1864, Wilno 1866, s.306; S. Gesket, Voennyje dejstvija., s.167 i n;W. Przyborowski, Dzieje 1863 r., t.I, s.191;N. Berg, Zapiski o powstaniu polskim 1863 i 1864 roku i poprzedzajacej powstanie epoki demonstracji od 1856 r., Kraków 1898, t.II, s.315; S. Zieliński, Bitwy, s.319; S. Płoski, Działania Rogińskiego, s.16; S. Góra, Partyzantka na Podlasiu, s.80-81; „Wiadomości z placu boju” 1863, nr 1, 3; „Czas” 1863, nr 37; „Dziennik Powszechny" 1863, nr 30; R. Rogiński, Zeznania, s.63.

19 W.Przyborowski, Dzieje 1863 r.,.I, s. 108-109; S. Zieliński, Bitwy, s. 320-321; Miłowidow, Rasporiażenija, s.569; S.Płoski, Działania Rogińskiego, s.18-19; S. Góra, Działalność powstańcza Romana Rogińskiego na Podlasiu, „Rocznik białostocki”, t.6: 1965, s. 380; Tenże, Partyzantka na Podlasiu, s.88-94; T.Mencel, Walenty Lewandowski i poczatki powstania styczniowego na Podlasiu, s.93; S.Chankowski, Powstanie styczniowe w Augustowskiem, s.92; S. Łaniec, Partyzanci Kresów, s.18-19; Tenże, Litwa i Białoruś, s.1; Tenże, Białoruś, s.40; Tenże, Pólnocna Suwalszczyzna, s.22. 
szybko i bezładnie, bez współdziałania z kolegami opuszczając strategiczny punkt. Chaotycznie kierowane przez komendantów poszczególne partie uległy naporowi wzmocnionego kolumną płk Krywonosowa zespołu gen. Zachara Maniukina (3 roty strzeleckie libawskiego pp, 2 roty batalionu strzelców, 5. rota kałużskiego pp oraz odwód-razem ok. 2500 żołnierzy). Odtąd rozpoczęła się niezwykła epopeja topniejących, ale i częściowo uzupełnianych sił powstańczych, dywersyjny marsz Rogińskiego w głąb ziem białoruskich. Dzięki pikietom i trafnemu wyborowi miejsca obozowania uszedł przy $50 \%$-stratach przed pościgiem gen. Iwana Nostitza (2 roty pskowskiego i rewelskiego pp, sotnia kozacka-ok. 490 żołnierzy, 4 działa) podczas przeprawy groblą rzeki Leśnej (11 II, Most Królowej) ${ }^{20}$. Z 85 podkomendnymi Rogiński napadł na obsadzone przez 250 inwalidów miasteczko, zdobywając na nich uzbrojenie (13 II, Prużany) ${ }^{21}$. Kolejny podział ,jednostki straceńców” nie kończył marszu, podczas którego kontynuowano niszczenie infrastruktury komunikacyjnej. Wobec obojętności okolicznej ludności upadł zamysł szturmu miasta (Pińsk). Mikroskopijne, 30-osobowe komando uległo ostatecznie przewadze 700 żołnierzy z 3 rot rewelskiego pp i sotni kpt. Jewdokimowa (26 II, Borki) ${ }^{22} .3$ marca w Turowie, po 24 dniach 750-kilometrowego rajdu w obcym, nieprzyjaznym terenie pojmano ich brawurowego dowódcę. ${ }^{23}$

Kilkumiesięczny kurs emigracyjny stanowił jedyne przygotowanie Józefa Oksińskiego, najwytrwalszego z insurekcyjnych komendantów w Kaliskiem. Oddelegowany do organizacji oddziału zmierzyć się musiał z trudnym wyzwaniem, czemu nie sprzyjało m.in. słabe zalesienie terenu, oraz „biały charakter” organizacji narodowej. Pierwszy miesiąc insurekcji jedyny aktywny tu dowódca poświęcił na przysposobienie ochotników do walki, unikając okrążenia, chociaż w lutym 1863 r. zdarzało się im wejść do opuszczonych miejscowości (Uniejów, Widawa) ${ }^{24}$. Kolejne zaangażowanie bojowe, po połączeniu z konnicą Aleksandra Litticha polegało na niepokojeniu okolic stolicy guberni i przejęciu miejscowości po utarczce ze strażą graniczną gen. Brummera (25 II 1863, Opatówek) ${ }^{25}$. Dowódczego kunsztu wymagało wyjście z otoczenia przez trzy silne kolumny mjr. Rukteszela, przeradzające się w bitwę odwrotową, z której uszło ok. 180 ludzi (26 II, Kuźnica Grabowska) ${ }^{26}$. 8-dniowa ucieczka

20 M.I.Cyłow, Sbornik rasporiażenij, s.306; W. Przyborowski, Historia 1863 r., t.I, s.201; S. Zieliński, Bitwy, s.320-321; S. Płoski, Działania Rogińskiego, s.21; S. Góra, Działalność powstańcza Romana Rogińskiego na Podlasiu, s.378-399; Tenże, Partyzantka na Podlasiu, s.97-98; S. Łaniec, Partyzanci Kresów, s.201; Tenże, Litwa i Białorus, s.62; Urzędowy wykaz, s.281; „Czas” 1863, nr 48, 67; „Wiadomości z pola bitwy”, 1863, nr 5.

21 S. Zieliński, Bitwy, s.321; A.F. Smirnow, Wosstanie, s.133-134; S. Góra, Działalność powstańcza Romana Rogińskiego, s.399-401; Tenże, Partyzantka na Podlasiu, s.98; S. Łaniec, Partyzanci Kresów, s.20; Tenże, Białoruś, s.42; Tenże, Litwa i Białoruś, s.64; „Wiadomości z pola bitwy” 1863, nr 5; „Czas” 1863, nr 48, 57; „Chorągiew Swobody" 1863, nr 2; R. Rogiński, Kartki, s.446; Tenże, Zeznanie, s.61,64.

22 N. Berg, Zapiski o powstaniu polskim, s.315; S. Zieliński, Bitwy, s.314/321; C. Zgorzelski, Powstanie styczniowe na terenie woj. nowogródzkiego, Wilno 1934, s.23-24; S. Góra, Działalność powstańcza Romana Rogińskiego, s.399-401; Tenże, Partyzantka na Podlasiu, s.98; S. Łaniec, Partyzanci Kresów, s.21; Tenże, Białoruś, s. 43; Tenże, Litwa i Białoruś, s.65; „Czas” 1863, nr 68; R. Rogiński, Zeznanie, s.64-69.

23 S. Zieliński, Bitwy, s.314; S. Góra, Działalnosć powstańcza Romana Rogińskiego, s.399-401; Tenże, Partyzantka na Podlasiu, s.98;S. Łaniec, Partyzanci Kresów, s.21;Tenże, Białoruś, s.43-44; Tenże, Litwa i Białoruś, s.65-66. 24 A. Czubiński, Powstanie 1863/1864 na ziemi kaliskiej, „Zeszyty naukowe UiAM”, nr 47 Historia nr 6:1961, s.42, 45; J. Oksiński, Wspomnienia z powstania polskiego, Warszawa 1965, s.44-45, 67, 69-70.

25 W. Przyborowski, Dzieje 1863 r., t.I, s.380; S. Zieliński, Bitwy, s.191; Urzędowy wykaz, s.304; „Wiadomosci z pola bitwy”, 1863, nr 4; „Dziennik Poznański”, 1863, nr 49, 50; „Czas” 1863, nr 54, 55; J. Oksiński, Wspomnienia, s.91-92.

26 S. Gesket, Voennyje deistvija, s.239; W. Przyborowski, Dzieje 1863 r., t.II, s.247; S. Zieliński, Bitwy, s.191-192 A. Czubiński, Powstanie 1863/64, s.150; Urzędowy wykaz, s.304; „Dziennik Powszechny” 1863, nr 54; „Wiado- 
przed nieprzyjacielskim pościgiem przerywana była starciami: m.in. zakończonym odwrotem bojem z odegnaniem liczącego 1/2 sotni kozackiej i 85 strzelców-ok. 130 żołnierzy zespołu bojowego mjr. Pisanko (3 III, Jawor), a także z kolejną kolumną, skutkującym rozsypką 166 insurgentów (5 III, Brodnia) ${ }^{27}$. Po odtworzeniu partyzanckiej partii doszło do kolejnych potyczek, podczas których zaatakowany przez prawie 200 piechoty i sotnię mjr. Merlina Oksiński przebił się na południe ze 150 podkomendnymi (4 IV, Rudniki), a następnie wyciął pododdział kozacki (Praszka, $11 \mathrm{IV})^{28}$. Maj przebiegał zgodnie z partyzancką zmiennością losu. Po połączeniu z Littichem miała miejsce walka ok. 900-osobowego oddziału z 4 rotami piechoty i 100 kozakami płk. Pomieranowa, ostatecznie z odwrotem - kosynierzy rozbiegli się, strzelcy ponieśli straty, a oddział zmniejszył się do półtysięcznych rozmiarów $(8 \mathrm{~V} \text {, Rychłocice })^{29}$. Następnie naczelnik wojskowy pow. piotrkowskiego zdobył niewielkie miasteczko, po czym odbyła się obrona pozycji obronnej, z wymuszeniem jej opuszczenia przy dwukrotnej przewadze oddziału mjr. Bentkowskiego $\left(25 \mathrm{~V}\right.$, Koniecpol) ${ }^{30}$. Wreszcie Oksiński przedsięwziął atak na transport kolejowy, połączony z krótkim kontaktem bojowym $\mathrm{z}$ dwiema rotami piechoty (27-28 V, Kłomnice-Kruszyna) ${ }^{31}$. W czerwcu odnotował kilka kolejnych starć odwrotowych skupiającego 1400 ludzi bojowego zespołu powstańczego (3 bataliony piesze, 1,5 szwadronu kawalerii), m.in. ujście z okrążenia, oderwanie się od pościgu, ucieczkę przed grupą bojową gen-mjr. Czengierego (ok. 2400 żołnierzy - 2 bataliony piesze, 2 szwadrony dragonów, pluton artyleryjski z 2 działami), oznaczającą rychłe rozpuszczenie podwładnych (27-29 VI, Przedbórz - Trzepnica - Skotniki) ${ }^{32}$. Pod naczelną komendą gen. Edmunda Taczanowskiego odbył z nową partią zbrojną kilka konnych utarczek (5 VIII, Łask; 22 VIII, Złoczew-z kolumną płk Tarasienkowa) ${ }^{33}$. Jesienią uzyskał organizacyjne sukcesy, tworząc niewielkie, zwrotne jednostki partyzanckie w poszczególnych powiatach i okręgach kaliskiego. Ostatnim przejawem dążeń Oksińskiego do zgrupowania znaczniejszych sił

mości z pola bitwy” 1863, nr 5; „Dziennik Powszechny” 1863, nr 50,52, 55; „Czas” 1863, nr 54,55, 72; J. Oksiński, Wspomnienia, s.93-102.

27 S. Gesket, Voennyje deistvija, s.284-285; W.Przyborowski, Dzieje 1863 r., t.II, s.248-249; S. Zieliński, Bitwy, s.193; A. Czubiński, Powstanie 1863/1864, s.151; Urzędowy wykaz, s.304; „Wiadomości z pola bitwy” 1863, nr 5; „Dziennik Powszechny” 1863, nr 54, 60; A. Giller, Polska $w$ walce. Zbiór wspomnień i pamiętników z dziejów $z$ dziejów naszego wyjarzmienia, t. 1, Paryż 1868, t.I, Przegrana pod Rudnikami. Rzecz spisana z notat naocznego swiadka, s.200; J. Oksiński, Wspomnienia, s.104-109.

28 S. Zieliński, Bitwy, s.195-196; Urzędowy wykaz, s.305; ,Wiadomości z pola bitwy”, 1863, nr 8, 9; „Dziennik Poznański” 1863, nr 83; „Czas” 1863, nr 88.

29 Zieliński, Bitwy, s.; A. Czubiński, Powstanie 1863/64, s.173; J. Oksiński, Wspomnienia, s.151-158; Urzędowy wykaz, s.306; „Wiadomości z pola bitwy” 1863, nr 12, 14; „Czas” 1863, nr 123, 130; „Dziennik Poznański” 1863, nr 119, 123, 124;

30 W. Przyborowski, Dzieje 1863 r., t.IV, s.230; S. Zieliński, Bitwy, s.202; A. Czubiński, Powstanie 1863/64, s.181; Urzędowy wykaz, s.295; Wiadomości z pola bitwy” 1863, nr 13 raport; „Dziennik Poznański” 1863, nr 121; „Czas” 1863, nr 119, 125; Sulima, Wspomnienia ułana z 1863 r., Poznań 1878, s.83-85: J. Oksiński, Wspomnienia, s.163-171.

31 S. Zieliński, Bitwy, s.202; J. Kukulski, Z dziejów powstania styczniowego w Piotrkowskiem, Piotrków Trybunalski 1991, s.29; „Czas” 1863, nr 123, 150; Sulima, Wspomnienia ułana,s.94; J. Oksiński, Wspomnienia,s.172-173.

32 S. Zieliński, Bitwy, s.206; J. Kukulski, Z dziejów powstania, s.29, 31; A. Czubiński, Powstanie styczniowe 1863/64, s.182; Urzędowy wykaz, s.296; Sulima, Wspomnienia ułana, s.100; J. Oksiński, Wspomnienia, s.175, 189200.

33 S. Zieliński, Bitwy, s.210; A. Czubiński, Powstanie 1863/64, s.193; Urzędowy wykaz, s.309; „Czas” 1863, nr 206; J. Oksiński, Wspomnienia, s.332. 
partyzanckich była tzw. koncentracja iwanowicka (350 piechurów i 35 jeźdźców) ${ }^{34}$, niezgodna jednak z koncepcją wojskowego naczelnika wojewódzkiego Franciszka Kopernickiego. Finałowym akordem zbrojnym miało być odparcie przez zabarykadowanych w dworskich zabudowaniach 20 konnych i 60 pieszych powstańców Oksińskiego 240 żołnierzy kolumny kpt. Straussa obejmującej 2 roty piechoty i 40 kozaków (25 II 1864, Chlewo) ${ }^{35}$. Do realizacji planów udziału w tzw. wyprawie wielkopolskiej wiosną 1864 r. nie doszło, m.in. wskutek gwałtownego i popędliwego charakteru Oksińskiego, skonfliktowanego z naczelnikiem Kopernickim.

Teodor Cieszkowski w okresie przedpowstaniowym zdobył na ziemi włoskiej zarówno wykształcenie (Genua-Cuneo), jak przysposobienie wojskowe (woluntariusz Garibaldiego). Mimo obecności Apolinarego Kurowskiego rzeczywistym dowódcą lutowego uderzenia ponad 200-osobowego oddziału (półszwadron konny, 50 kosynierów, 50 strzelców, 50 ochotników) na garnizon straży granicznej w opanowanym przez powstańców trójkącie granicznym był Cieszkowski. Trzykrotny szturm budynku dworcowego zakończył się powodzeniem dzięki przytomności umysłu i brawurze odwadze Cieszkowskiego, zbierającego załamanych chwilowym niepowodzeniem podwładnych i wiodącego ich do ostatecznego szturmu (6 II 1863, Sosnowiec) ${ }^{36}$. Po czasowym komenderowaniu załogą miasteczka (Dąbrowa Górnicza), klęsce pod Miechowem (gdzie 300 podkomendnych Cieszkowskiego spóźniło się) oraz kuracji zdrowotnej rozpoczął kilkunastodniowy etap niezależnej aktywności ${ }^{37}$. Zagon z woj. krakowskiego w Kaliskie wiązał się z potyczką, podczas której Cieszkowski zaatakowany przez płk. Alenicza (2 roty piesze i 50 kozaków, tj. 450 żołnierzy z 2 działami) w uporządkowanym stylu wymknął się z obławy (26 II, Pańki ${ }^{38}$. Po powrocie w Krakowskie opanował sytuację podczas nieoczekiwanego nieprzyjacielskiego napadu, odpierając szturmy na miasteczko i tyłowym natarciem części oddziału, doprowadzając do popłochu grupę pościgową Alenicza (1 III, Mrzygłód) ${ }^{39}$. Po dwutygodniowym pobycie w korpusie Mariana Langiewicza realizował misję formacyjno-dywersyjną w południowej części woj. kaliskiego, alarmując drobne garnizony (14 III, Radomsko), zrywając trakcje elektryczne, mosty i połączenia kolejowe ${ }^{40}$. Dwa kolejne starcia polegały na obronie obozów powstańczych: Cieszkowski został wskutek zaniedbania środków ostrożności niespodziewanie zaatakowany przez 400 żołnierzy z 2 rot pieszych mjr. Leona z Częstochowy (22 III,

\footnotetext{
34 A. Czubiński, Powstanie 1863/64, s.214.

35 S. Zieliński, Bitwy, s.219; A. Czubiński, Powstanie 1863/64; „Gazeta Narodowa” 1863, nr 55, 56; ,Głos z Litwy” 1863, nr 5; „Dziennik Poznański” 1863, nr 50; „Wiek” 1863, nr 19.

36 W. Przyborowski, Dzieje 1863 r., t.I, s.143; S. Zieliński, Bitwy, s.160; P.Bańkowski, Z dziejów powstania styczniowego na Kielecczyźnie, „Pamiętnik Kielecki” 1947; R. Szwed, Powstanie styczniowe w Radomszczańskiem, Radomsko 1987, s.64-68; raport Kurowskiego do RN, 8 II w: Dokumenty terenowych władz wojskowych powstania styczniowego, Wrocław-Warszawa-Kraków 19, s.442-443; „Czas” 1863, nr 29,36; „Dziennik Powszechny” 1863, nr 32, 37; S. Szulc, Pamiętnik księdza kapelana w: Polska w walce, red. A.Giller, t.1, s.86.

37 W. Przyborowski, Dzieje 1863 r., t.I, s.241; S. Zieliński, Bitwy., s.160; W. Tokarz, Kraków w początkach powstania styczniowego i wyprawa na Miechów, Kraków 1914, t.II, s.156; P.Bańkowski, Z dziejów powstania, s.139.

38 S. Gesket, Voennyje deistvija., s.281; W. Przyborowski, Dzieje 1863 r., t.II, s.200; S. Zieliński, Bitwy, s.192; Urzędowy wykaz, s.304; „Wiadomości z pola bitwy” 1863, nr 5; „Dziennik Poznański” 1863, nr 5.

39 S. Gesket, Voennyje deistvija., s.281; W. Przyborowski, Dzieje 1863 r., t.V, s.20; S. Zieliński, Bitwy, s.163; R. Szwed, op. cit., s.83; „Wiadomości z pola bitwy” 1863, nr 5; „Czas” 1863, nr 50; „Dziennik Poznański” 1863, nr 55, 67; „Dziennik Powszechny” 1863, nr 54; S. Szulc, Pamiętnik w: W 40 rocznice, s.101.

40 S. Zieliński, Bitwy, s.193; „Czas”1863, nr 61,63; „Dziennik Poznański” 1863, nr 84.
} 
Kuźnica Masłowska), co trójstronnie osaczanego zmusiło do zawrócenia w Krakowskie ${ }^{41}$. Kolejne starcie obronne z mjr Pisanko (2 roty piechoty, sotnia kozaków - 490 żołnierzy) przeradzało się momentami w zaczepne, do tego stopnia, że ostateczny kontratak skłonił Rosjan do odejścia (27 III, Radoszewice) ${ }^{42}$. Po krótkim załamaniu, wynikającym z konieczności rozwiązania niezdolnego do aktywnych działań oddziału wrócił Cieszkowski do prac organizacyjnych. Życie pozostającego w ciągłym ruchu komendanta kończy się wraz z likwidacją 28-konnego zawiązka nowej formacji przez blisko 500 piechurów i kozaków mjr. Merlina (10 IV, Broszęcin) ${ }^{43}$.

Drugiego z kresowiaków przeszkolonego w Polskiej Szkole Wojskowej na włoskiej ziemi, Feliksa Wysłoucha uznaje się za inicjatora pierwszego efemerycznego oddziału partyzanckiego na Litwie, co miało nastąpić z końcem stycznia 1863 r. (Zułów). Od początku inicjatywa powstańcza ukierunkowana została m.in. na zajęcie miejscowości (7 II 1863, Żeladź), choć pokonany tam przez pluton newskiego pp i $1 \frac{1}{2}$ szwadronu kozaków Wysłouch wycofał się i rozpuścił ludzi ${ }^{44}$. Po przerwie doszło do kolejnej, nierozstrzygniętej potyczki (22 II, Daukszyszki) ${ }^{45}$. Wiosną stoczył Wysłouch jako wojskowy naczelnik pow. trockiego ze 130 ludźmi bitwę na przyjętej dzięki informacjom zwiadowczym pozycji obronnej, odpierając rotę i 17 kozaków kpt. Fiedotowa (16 IV, Antokolce) ${ }^{46}$. Następnie porządkował się Horodeńskiemu-Kieżgajle i A. Stabrowskiemu i walczył na czele 320 insurgentów wraz z naczelnikiem wileńskim Horodeńskim w zwycięskim boju z częścią ponadtysiącosobowej kolumny płk. Kremera (30 IV, Szeszole). ${ }^{47}$ Po bitwie zgrupowania z zespołem bojowym płk. Tisdela, wskutek której doszło do podziału zgrupowania Stabrowskiego i Jana Sendka, Wysłouch z 250 podkomendnymi został podczas marszu otoczony przez kolumnę ppłk. Czekiesowa z kostromskiego pp (2 roty, 20 kozaków -ok. 610 żołnierzy), jednak udało mu się przełamać pierścień okrążenia (11 VII, Żyżmory ${ }^{48}$. Po miesiącu, ponownie ścigany zdecydował się

\footnotetext{
41 S. Gesket, Voennyje deistvija, s.286; S. Zieliński, Bitwy, s.166; R. Szwed, op.cit., s.110, 112; Urzędowy wykaz, s.293; „Wiadomości z pola bitwy” 1863, nr 7; „Czas” 1863, nr 69, 70; „Dziennik Poznański” 1863, nr 71.

42 S. Zieliński, Bitwy, s.195; J. Kukulski, Z dziejów powstania, s.26; A. Barszczewska, Udział Łodzi i okręgu łódzkiego w ruchach narodowowyzwoleńczych 1795-1864, Łódź 1971, s.281; T.Olejnik, Bitwa pod Radoszewicami 27 III 1863. Przyczynek do dziejów powstania styczniowego na ziemi wieluńskiej, „Sieradzkie Roczniki Muzealne”, t.6: 1986, s.81-94; „Wiadomości z pola bitwy” 1863, nr 8; „Dziennik Poznański” 1863, nr 73, 75-raport Calliera; „Czas” 1863, nr 73, 76; „Dziennik Powszechny” 1863, nr 71.

43 S. Zieliński, Bitwy, s.195-196; J. Milczarek, Powstanie styczniowe w Sieradzkiem, Sieradz 1983, s.23; S. Szulc, op.cit., s.109; Urzędowy wykaz, s.305; „Wiadomosci z pola bitwy” 1863, nr 9; „Czas” 1863, nr 85,89, 90; „Dziennik Poznański" 1863 , nr 91.

44 S. Zieliński, Bitwy, s.276-277; J.Jakubianiec-Czarkowska, Powstanie w powiecie święciańskim, Święciany 1934, s.21-29; A.F. Smirnow, Wosstanije, s.138-139; S.Łaniec, Białoruś, s.51; Tenże, Powstanie styczniowe na Litwie, Olsztyn 2000, s.47-48; Tenże, Tenże Litwa i Białoruś, s.67.

45 A.I. Miłowidow, Piereczien bojewych stolknowieenij, s.3.

46 S. Zieliński, Bitwy, s.278-279; M.I. Cyłow, Sbornik rasporiażenij, s.307; A.Smirnow, Wosstanije, s.138-139; S. Łaniec, Powstanie styczniowe na Litwie, s.61-62; Tenże, Litwa i Białoruś, s.82; „Wiadomości o powstaniu na Litwie” 1863, nr 3; „Wiadomości z pola bitwy” 1863, 22 IV, 28 IV; „Czas” 1863, nr 94, 98, 102, 103; „Dziennik Poznański” 1863, nr 94.

47 S. Zieliński, Bitwy., s.280; M.I.Cyłow, Sbornik rasporiażenij, s.307; A. Krzyszkowska, Powstanie styczniowe na Wileńszczyźnie, Wilno 1934, s.37-38; S. Łaniec, Powstanie styczniowe na Litwie, s.63; Tenże, Litwa i Białoruś, s.83-84; „Wiadomości o powstaniu na Litwie” 1863, nr 5; „Dziennik Poznański” 1863, nr 108; „Czas” 1863, nr 107, 108.

48 S. Zieliński, Bitwy, s. 285; M.I. Cyłow, Sbornik rasporiażenij, s. 310; A. Krzyszkowska, Powstanie styczniowe na Wileńszczyźnie, s.38; S. Łaniec, Powstanie styczniowe na Litwie, s.119; Tenże, Litwa i Białoruś, s.153
} 
na konfrontację z 200-osobową rotą Tisdela: zrazu udanie (20 VIII, Antopojce), nazajutrz rozbity (21 VIII, Petraszyszki) ${ }^{49}$. Jego aktywność polegała na przemarszach i potyczkach z patrolami piechoty, jazdy i kozaków. Obecność Wysłoucha na scenie powstańczej spina klamrą silny akord: w fazie zamierania insurekcji wileńskiej dokonał napadu na nieprzyjacielski zespół pacyfikacyjny, rozpraszając w ok. 400 ludzi rotę pieszą i sotnię kozacką, tj. ok. 245 carskich żołnierzy (Żyżmory, $20 \mathrm{X})^{50}$.

\section{Dowódcy na obiecującym poziomie}

Aleksander Littich, uznając naczelną komendę Józefa Oksińskiego, kolegi z emigracyjnej szkoły wojskowej, od lutego do lipca 1863 r. współdziałał z nim w roli komendanta jazdy oddziałowej w Kaliskiem i Sandomierskiem, czy też organizatora partii w kwietniu. Bilans nieco przypadkowej samodzielności (po oddzieleniu się w trakcie bitwy) wypada remisowo, podobne jak pierwsze samodzielne starcie naczelnika sił zbrojnych pow. wieluńskiego z 2 rotami piechoty i 50 kozakami płk. Suwarowa (450 żołnierzy), do którego został zmuszony (23 IV 1863, Wąsosz-Więcki) ${ }^{51}$. Unikając otoczenia, przesunął linię bojową z brzegu do wnętrza lasu, gdzie doszło do wymiany ogniowej, przerywanej akcjami kozaków. Podczas wycofywania się partia Litticha uległa rozsypce. W późniejszym okresie rozegnanie nieco słabszej od własnego 60-osobowego półsotni setnika Kriukowa (3 VII, Kaszewice) okupił niespodziewanym rozproszeniem powstańczego obozu przez sotnię por. Fiedorowa i niedobitki Kriukowa (4 VII, Chorzenice) ${ }^{52}$. Niezależną komendę sprawował jeszcze jesienią nad resztkami mazowieckiego zgrupowania Roberta Skowrońskiego.

Absolwent włoskiej placówki emigracyjnej, Maksymilian Wacław Broniewski rozpoczął bojowy szlak od organizacji partii zbrojnej w Płockiem pod koniec stycznia $1863 \mathrm{r}$. W lutym dołączył do Władysława Cichorskiego-Zameczka, przyuczał się do rzemiosła wojskowego u boku kolejnych naczelników powiatowych, aby jako dowódca największego oddziału stanąć na czele zgrupowania w Ostrołęckiem. Doszło tam do kilkufazowych zmagań, kiedy oddziały po Karolu Frycze (600) i Polikarpie Dąbkowskim (ok. 200 jeźdźców) pod dowództwem Broniewskiego w połączeniu z Ludwikiem Lutyńskim (200 strzelców), a także partie chłopskie Stanisława Mańkowskiego (100), Jana Nowaka (50) oraz niezorganizowanych z okolic Ostrowia i Broku (ok. 50) w ok. 1200-1400 insurgentów przyjęły natarcie 3 rot piechoty, szwadronu huzarów, 50 kozaków gen.-mjr. Tolla, mjr. Zassa i mjr. Suchotina (ok. 850 żołnierzy). Nierozstrzygnięta bitwa skończyła się odwrotem w obliczu rosyjskiej

\footnotetext{
49 S. Zieliński, Bitwy, s.285; A. Krzyszkowska, Powstanie styczniowe na Wileńszczyźnie, s.39; S. Łaniec, Powstanie styczniowe na Litwie, s.120; Tenże, Litwa i Białoruś, s.154; „Czas” 1863, nr 200, 205; „Dziennik Poznański” 1863, nr 205, 210.

50 S. Zieliński, Bitwy, s.286, 306-308, 539; L. Ratajczyk, Polska wojna partyzancka 1863-1864. Okres dyktatury Romualda Traugutta, Warszawa 1966, s.224; S. Łaniec, Powstanie styczniowe na Litwie, s. 138-139; Tenże, Litwa i Białoruś, s.174; „Czas” 1863, nr 254, 255.

51 S. Zieliński, Bitwy, s.198; J. Gąsiorowski, Bitwa pod Wąsoszem 23 kwietnia 1863 r., Częstochowa 1938; A. Czubiński, Powstanie 1863/64, s.45; J.Związek, Bitwa pod Wasoszem (23 IV 1863) na tle walk powstańczych na Ziemi Częstochowskiej, „Częstochowskie Wiadomosci Diecezjalne”, r.57: 1983, nr 19, s.206-219; Urzędowy wykaz, s.306; „Wiadomości z pola bitwy” 1863, nr 10 raport; „Dziennik Powszechny” 1863, nr 96; „Czas” 1863, nr 94,97,98, 99; „Dziennik Poznański” 1863, nr 98.

52 S.Zieliński, Bitwy, s. 207;Urzędowy wykaz, s.308; „Dziennik Poznański” 1863, nr 160; „Czas” 1863, nr 161, 162.
} 
odsieczy (3 VI 1863, Nagoszewo) ${ }^{53}$. Wedle innej wersji najpierw nastąpił partyzancki atak na rosyjską kolumnę postojową ( 2 roty piesze, 2 szwadrony i sotnia -ok. 830 żołnierzy), potem odparcie kolumny Suchotina (3 roty, szwadron huzarów i kozacy -ok. 830 żołnierzy) i wreszcie wycofanie się w zwarciu z kolumnami mjr. Zassa (3 roty -600 żołnierzy) i gen. Tolla (3 roty -600 żołnierzy). Razem walczyło ok. 2850 rosyjskich żołnierzy. Rolę polskiego komendanta można dostrzec podczas drugiej fazy walk, kiedy usiłował wykorzystać walory leśno-bagiennej bazy do przeprowadzenia podwójnej zasadzki z udziałem piechurów. Słabość materiału ludzkiego spowodowała ewolucję starcia w bój obronny, a interwencja okolicznych włościan w pościgowy. Nadejście ostatniej kolumny przeciwnika oznaczało konieczność skrzydłowego przedarcia się nad rzekę i podziału zgrupowania. Broniewski ponownie podporządkował się innym.

Bolesław Kołyszko to jeden z dwóch uczestników emigracyjnego kursu wojskowego związanych z litewskim teatrem zmagań zbrojnych. Pochodząc z Wileńskiego zapisał się w dziejach insurekcyjnej Kowieńszczyzny. Jego zasługą stało się przeobrażenie ochotników przybyłych do obozu w quasi-regularny, 400-osobowy tzw. pułk dubiski, jednak niedostateczne przeszkolenie i uzbrojenie w połączeniu z niedopatrzeniem środków ostrożności spowodowało, że wysiłki powstrzymania zaskakującego natarcia kaporskiego pp mjr. Stepanowa (ok. 3300- 3600 żołnierzy) uzupełnionego nieprzyjacielskim obejściem od tyłu zakończyły się rozpierzchnięciem podwładnych Kołyszki (29 III 1863, Wysoki Dwór) ${ }^{54}$. W nadrzecznych starciach tysięcznego zgrupowania pod komendą Tomasza Kuszłejki, dowodził prawym skrzydłem-najpierw przeciw dwóm, blisko 2-tysięcznym kolumnom z Rosień i Kiejdan, następnie w wymianie ogniowej z ok. 900 żołnierzami (1, 5 IV Lencza) ${ }^{55}$. Ponowny podział jego jednostki (obecnie 70 insurgentów) omal nie zakończył się jej likwidacją przez 2,5 roty (500 żołnierzy) płk. Bożerianowa, jednak udało się przerwać okrążenie i wejść w głąb lasów (11 IV, Misiuny $)^{56}$. Dalszy szlak bojowy Kołyszki wiąże się z kampanią Zygmunta Sierakow-

\footnotetext{
53 N. Berg, Notatki o polskich powstaniach., t.III, s.226; W.Przyborowski, Dzieje 1863 r., t.IV, s.276; S. Zieliński, Bitwy, s.236; M.Bartniczak, Bitwa pod Nagoszewem 3 VI 1863, „Rocznik Mazowiecki”, 1972, t.4. s.181; S. Góra, Partyzantka na Podlasiu, s.141; Urzędowy wykaz, s.317; „Wiadomości z pola bitwy” 1863, nr 15; „Dziennik Powszechny” 1863, nr 125; „Czas” 1863, nr 132, 156; Z. Chądzyński, Wspomnienia powstańca z lat 1861-1864, Warszawa 1963, s.122-123; Pamiętnik powstańca Wacława Broniewskiego, BUW, rkps 1345; Rys życia M.W. Broniewskiego, BN, rkps II 6515, k.26, 28, 30, 31, dod. 30.

54 Miłowidow, Pierieczeń bojewych stolknowienij, t.II, s.94; N.I. Cyłow, Sbornik rasporiażenij., S. Zieliński, Bitwy, s.288; A. Smirnow, Wosstanije, s.148-151; W. Karbowski, Kampania Zygmunta Dołegi-Sierakowskiego na Żmudzi w 1863 r., „SiMdHW”, t. XXI, 1978, s.234; s.306; S. Łaniec, Litwa, s.28; Tenże, Powstanie styczniowe na Litwie, s.56-57; Tenże, Litwa i Białoruś, s.73; Tenże, Rajdy partyzanckie i bitwy Bolesława Kołyszki na Kowieńszczyźnie (wiosna 1863 roku) w: Społeczeństwo i polityka w dziejach Polski i Europy. Studia do dziejów politycznych $i$ wojskowych dedykowane Profesorowi Benonowi Miskiewiczowi z okazji jubileuszu 70-lecia urodzin, red. A.Czubiński, B.Lapis, Cz.Łuczak, Poznań 2002, s.418-419; „Ojczyzna” 1864 nr 124 Monografie; „Dziennik Poznański” 1863, nr 81,94; „Wiadomości z pola bitwy”, 1863 nr 8; „Czas” 1863, nr 82,84,86; „Ojczyzna” 1865, nr 69; J. Laskarys, Wyprawa Sierakowskiego na Kurlandię w 1863 r. w: Pismo zbiorowe. Towarzystwo Naukowe Młodzieży Polskiej, t.1:1865, Bendlikon, s.37-43.

55 S. Zieliński, Bitwy, s.288-289; A. Smirnow, Wosstanie, s.50; S. Łaniec, Litwa, s.34; Tenże, Powstanie styczniowe na Litwie, s.77-78; Tenże, Dowódcy i bohaterowie powstania, s.44-45; „Wiadomości z pola bitwy” 1863, nr 9; „Wiadomości o powstaniu na Litwie” 1863, nr 3-raport naczelnika woj. kowieńskiego; „Czas” 1863, nr 91, 93, 261-korespondencja ze Żmudzi 1 XI; „Dziennik Poznański” 1863, nr 94; J. Laskarys, Wyprawa Sierakowskiego, s.40-41.

56 S. Zieliński, Bitwy, s.289; A. Smirnow, Wosstanije, s.151; S. Łaniec, Litwa, s.39; Tenże, Powstanie styczniowe na Litwie, s.80; Tenże, Litwa i Białorus, s.93-94; Wosstanije w Litwie i Biełorussii 1863-1864, Wrocław-Warszawa-Kraków, s.201-Zeznanie Kołyszki.
} 
skiego, który doceniając walory przybysza awansował go, a w marszu ku Kurlandii mianował dowódcą lewoskrzydłowej kolumny (I i III batalion w sile ok. 300-400 osób), zdążającej na Birże. To on rozpoczął trzydniową batalię na Żmudzi (7 V, Hudyszki) ${ }^{57}$. Kołyszko związał kolumnę mjr. Merlina (1,5 roty pieszej kaporskiego pp, 70 kozaków-ok. 320 żołnierzy) aż do uzyskania wsparcia przez kolejny batalion oraz kolumnę marszową Sierakowskiego. Nazajutrz, w oczekiwaniu na odsiecz partii ks. Antoniego Mackiewicza walczono aż do momentu uzyskania przewagi przez wzmocnionego posiłkami przeciwnika. 9 V Kołyszko trafił do niewoli, a 3 VI został rozstrzelany w Wilnie ${ }^{58}$.

Pawel Suzin zamierzał przybyć do powstania już w lutym 1863 r., jednak jego oddział przewidziany do przekroczenia kordonu w Płockiem został rozproszony przez wojsko pruskie. W maju stanął na czele grupki ochotników w pow. mariampolskim woj. augustowskiego, wkrótce po połączeniu z partią zbrojną W. Kamińskiego (4. oddział województwa liczył 265 uzbrojonych i 40 bezbronnych) odbył potyczkę w wykonaniu podjazdów polskiego i rosyjskiego (22 V, Poszławanty) ${ }^{59}$. Walna konfrontacja z kolumną płk. Manowskiego (2,5 roty piechoty, kozacy, szwadron dragonów-ponad 700 żołnierzy, 2 działa) rozpoczęła się od zaangażowania w walkę powstańczej awangardy $\left(23 \mathrm{~V}\right.$, Buda/Balwierzyszki) ${ }^{60}$. Ostrzelani ogniem sztucerowym, następnie dwoma działami insurgenci skryli się za budynkami i cofnęli się do lasu, kontynując wymianę ogniową. Wobec próby otoczenia Suzin przeprowadził manewr wejścia w głąb lasu, gdy zaś przeciwnik wycofał się, powrócił na wcześniejsze stanowisko. Oddział Suzina zerwał komunikację kolejowo-telegraficzną na linii kolejowej oraz przeprowadził serię przygranicznych manewrów, po czym z północnej części województwa przemieścił się na południe. Tam na czele zgrupowania oddziałów własnego, Kamińskiego, Wiktora Hłaski i Władysława Brandta, choć naciskany przez 5 rot piechoty z 2 szwadronami huzarów i 2 działami (1400 żołnierzy) urządził nadrzeczną zasadzkę, ostrzeliwując nieprzyjacielskich piechurów i jeźdźców kpt. Sterna vel Gwiazdowskiego (rota gwardii, jazda -ok.200 żołnierzy), którzy po wymianie ogniowej wycofali się (20 VI, Olita $)^{61}$. Zmieniono miejsce obozowania powstańczych oddziałów Suzina, Brandta, Hłaski i Józefa Gleba-Kazańskiego, a po rozpoznaniu terenu zajęto obronną pozycję nad jeziorem

\footnotetext{
57 A. Smirnow, Wosstanije, s.197; W. Karbowski, Kampania Dołegi-Sierakowskiego, s.273-274; S. Łaniec, Zygmunt Sierakowski, Olsztyn 1999, s.80-81; Tenże, Litwa, s.55.

58 W. Przyborowski, Dzieje 1863 r., t.III, s.99-100, S.I. Cyłow, Sbornik rasporiażenij, s.49; S. Zieliński, Bitwy, s.293-294; A. Smirnow, Wosstanie, s.198-200; W. Karbowski, Kampania Dołegi-Sierakowskiego, s.278, 281; S. Łaniec, Sierakowski, s.83-85; Tenże, Litwa, s.58-59; Wosstanie w Litwie i Biełorussii, s.201-202.

59 S. Zieliński, Bitwy, s.259-260; S. Chankowski, Powstanie styczniowe w Augustowskiem, s.122; I. Karpowicz, Imć Pana Rotmistrza, powstańca z r. 1863 wspomnienia, Wilno 1928., s.66-69.

60 S. Zieliński, Bitwy,s.259-260; S.I. Cyłow, Sbornik rasporiażenij, s.308; Z. Kolumna,[A.Nowolecki] Pamiatka dla rodzin polskich: krótkie wiadomosci biograficzne o straconych na rusztowaniach, rozstrzelanych, poległych na placu boju, oraz zmarlych w więzieniach, na tułactwie, Kraków 1868,t.II, s.62-63; S. Chankowski, Powstanie styczniowe w Augustowskiem, s.122; Urzędowy wykaz, s.322; , Wiadomości z pola bitwy” 1863, nr 12, 13; , Czas”, 1863, nr 129, 130; , Dziennik Poznański” 1863, nr 120; 124 raport Suzina, 127, 132; , Nadwiślanin” 1863 nr 61; S. Katyll, Opis bitew stoczonych w r.1863 pod Balwierzyszkami i pod Staciszkami. Śmierć Pawła Suzina, „Zdrowie” 1904, s.235-239; R. Błoński, Pamiętnik z Augustowskiego 1863 r. w: Polska w walce. Zbiór pamiętników, wyd. A. Giller, t.2, Kraków 1875, s.396-398; W. Brandt, Mój udziat w powstaniu w: W 40 rocznicę, Lwów 1903, s.78-79.

${ }_{61}$ S. Zieliński, Bitwy, s.261; N.I. Cyłow, Sbornik rasporiażenij, s.309; Krzyszkowska, Powstanie w pow. święciańskim., s.27; S. Łaniec, Powstanie styczniowe na Litwie, s.69-70; Tenże, Pólnocna Suwalszczyzna, s.43; R. Błoński, Pamiętnik z Augustowskiego 1863 r., s.391, 399; „Dziennik Poznański” 1863, nr 167-raport; „Czas” 1863, nr 146, 147, 157; ,Niepodległość” 1867 nr 36.
} 
(21 VI Stragiszki ${ }^{62}$. Przy wyrównanych siłach lub niewielkiej przewadze rosyjskiej kolumny kpt. Sterna vel Gwiazdowskiego połączonego z płk. Skordulą (3 roty piesze,kozacy -razem ponad 600 żołnierzy), zamiast przygotować zasadzkę z możliwością zajęcia jej tyłów awangarda powstańcza zaalarmowała nadchodzących. Decyzja Suzina o osobistym pokierowaniu ostrzałem karabinierskim wywołała zamieszanie w szeregach przeciwnika, stąd plan okrążenia Rosjan za pomocą prawoskrzydłowych kosynierów i wyjścia im na tyły. Ze względu na negatywne oddziaływanie ostrzału na kosynierów, Suzin postanowił z garstką karabinierów pociągnąc ich za sobą, jednak podczas odwrotu został zabity. Oznaczało to rozproszenie oddziału, niewspartego przez partię zbrojną jednostkę Hłaski.

\section{Dowódca przeciętny}

Dowódcze umiejętności Władysława Jabłońskiego można ocenić na podstawie znaczącej w skali powstania bitwy (3 II 1863, Węgrów) ${ }^{63}$. Trzytysięczne zgrupowanie stawiło bowiem opór nieprzyjacielskim kolumnom (z północy 3 bataliony wołyńskiego, halickiego i witebskiego pp, sotnia kozacka i 2 działa 2. brygady artylerii w dwóch kolumnach ppłk. Kriwonosowa z Małkini oraz ppłk. Botempsa z Łochowa -ok.2500 żołnierzy; z południa siedlecka kolumna płk. Papaafanasopuło - 9, 11, 12 rota kostromskiego pp, 4 szwadron ułanów smoleńskiego pp, inny szwadron, dywizjon artylerii konnej - ok. 900 żołnierzy, 4 działa), chociaż w zasadniczym boju około 2 tys. powstańców zmagało się z podkomendnymi carskiego oficera greckiego pochodzenia.

Jabłonowski, Podlasiak z urodzenia, formalnie z Janem Matlińskim współdowódca zgrupowania, de facto przyjął ciężar dowodzenia. Korzystnie wypada decyzja komendantów o rozprawieniu się z każdą z nadciągających regularnych kolumn z osobna. Także wstępna utarczka liczniejszej o $10 \%$ grupy powstańczej z jedyną kolumną rosyjską, zaangażowaną w boju, wypadła dość korzystnie - wstrzymano jej pochód, uzyskano wiedzę o potencjale i kierunku marszu i zaalarmowano miasto (Jabłonowski osobiście wiódł konną szarżę), aczkolwiek zaniechano ruchów zaczepnych na szerszą skalę. Podjęta na dowódczej naradzie, umotywowana patriotycznie i emocjonalnie decyzja o obronie Węgrowa, ze względu na położenie na brzegu rzeki i skrzyżowaniu dróg, w otoczeniu wzgórz, oznaczała oddanie przeciwnikowi korzystniejszej pozycji, a przypadku dysponowania przezeń artylerią czyniła realizację planu niemożliwą. Ambitnie zakrojona była próba dowodzenia całością sił w mieście i na wysuniętych pozycjach, jednak wobec ranienia Jabłonowskiego Matliński improwizował defensywę. Szef sztabu przejął obowiązki naczelnego komendanta, a Jabłonowski wzmiankowany jest w źródłach jako inicjator działań osłonowych wycofującego się

62 Z. Kolumna, op.cit., cz.II, s.63; S. Zieliński, Bitwy, s.261-262; S. Chankowski, op.cit., s.123; S. Laniec, Partyzanci Kresów, s.104-105; Tenże, Powstanie styczniowe na Litwie, s.69-70; Tenże, Pólnocna Suwalszczyzna, s.4344; raport Andruszkiewicza dla RN 14 VII 1863; Dokumenty terenowych władz wojskowych, s.40-41; „Czas” 1863, nr 147; „Dziennik Poznański” 1863, nr 156, 167; Sz. Katyll, Opis bitew, s.240-250; R. Błoński, Pamiętnik z Augustowskiego, s.398-401; I. Karpowicz, Pamiętnik Imć Pana Rotmistrza, s.74-75.

63 W. Przyborowski, Dzieje 1863 r., t.I, s.178-179; S. Gesket, Voennyje deistwija, s.169-173; S. Zieliński, Bitwy, s.335-340; E. Kozłowski, Od Wegrowa do Opatowa, 3 II 1863-22 II 1864, Wybrane bitwy z powstania styczniowego, Warszawa 1962, s.; S. Góra, Partyzantka, s.81-86; „Wiadomości z pola bitwy”, 1863 nr 1; „Czas” 1863 nr 34; „Dziennik Powszechny” 1863, nr 28; „Dziennik Poznański” 1863, nr 31, 36; T.Wyszomirski, Bitwa pod Wegrowem stoczona przez powstańców z wojskiem carskim 3 II 1863 w świetle relacji jej uczestnika Stanisława Krzemieniewskiego, „SiMdHW”, 1962, t.III, cz.2, s.327; Urzędowy wykaz, s.28; N.Wronowski, Węgrów. Siemiatycze w: W 40 rocznicę, s.513; F.Lewicki, Węgrów. Obrazek historyczny pamięci przyjaciela, Stanisławów 1881; W. Jabłonowski, Pamiętnik, Biblioteka PAN Kraków 2189/1, t.1, k.436-437. 
zgrupowania. Z oddziałem strzelców, a przede wszystkim kosynierami, których kontratak na wdzierających się do miasteczka żołnierzy omal nie doprowadził do zdobycia armat, na tyle umiejętnie zabezpieczył wyjście insurgentów, że uniknęli pościgu i okrążenia. Nie do podważenia pozostaje zaangażowanie i odwaga naczelnika, podobnie jak niedostatek praktycznego doświadczenia. Poprowadzenie otwartej konfrontacji największego, choć słabo wyszkolonego powstańczego zgrupowania z regularną, dobrze wyposażoną i przygotowaną formacją nieprzyjacielską, okazało się nad siły młodocianego ,genueńczyka”. Nie potrafił wykorzystać liczebnej przewagi (3,5:1, bezpośrednio w obronie miejscowości 2:1), ani ewidentnych błędów przeciwnika. Obydwaj komendanci wykruszającego się po drodze oddziału, choć dołączyli do zabużańskiego zgrupowania, uniknęli starcia (6 II, Siematycze) ${ }^{64}$. Jabłonowski dowodził jeszcze podczas choroby Teodora Cieszkowskiego jego oddziałem, ale po miechowskiej katastrofie także udzieliła mu się panika i wyjechał do Galicji ${ }^{65}$.

\section{Dowódcy nisko oceniani}

Wiktor Jurkowski przyswojoną w szkole emigracyjnej teoretyczną wiedzę potrafił spożytkować głównie na polu organizacyjnym (w marcu, kwietniu i czerwcu 1863 r.), gdyż cztery podejścia do dowodzenia w Płockiem kończyły się katastrofą. Dysponując niedoświadczonymi podwładnymi, zamiast ukrywać się ze stuosobową partią zbrojną w leśnych ostępach, stacjonował we wsi, gdzie niedopatrzenie ubezpieczeń było przyczyną ataku zespołu esauła Dukmasowa (120 pieszych, 40 kozaków), rozbicia i ucieczki niedobitków (12 III 1863, Rydzewo $)^{66}$. Element zaskoczenia wystąpił także podczas musztry 150 ochotników prowadzonej nieopodal obronnie położonego obozu, a mimo kilku prób nie powiodło się sformowanie linii przeciw rocie pieszej kpt. Prowolskiego (14, 16 IV, Skępe, Koziołek) ${ }^{67}$. Zbierający się, 300-osobowy oddział rozbił zespół proporszczyka Wasilewskiego (4 VI, Bąkowo $)^{68}$, a ostatecznie ok. 245 żołnierzy z roty pieszej i 1/2 sotni kozackiej kpt. szt. Kenstowicza (9 VII, Szczutowo-Blizne) ${ }^{69}$. Jurkowski zrzekł się wówczas dowodzenia na rzecz naczelnika wojskowego pow. lipnowskiego mjr. Piotra Czarlińskiego.

Anastazy Mossakowski, niczym niewyróżniający się dowódca kwietniowej wyprawy galicyjskiej sprawiał wrażenie apatycznego, pozbawionego wiary w siebie i sukces przedsięwzięcia. Zastanawia to o tyle, że praktyczne doświadczenie z ekspedycji Garibaldiego uzupełnił teoretyczną podbudową w Genui i Cuneo. Realizacja planu połączenia w lasach

64 Zob. przypis nr 19.

65 Zob. przypis nr 37.

66 N. Berg, Zapiski o polskich powstaniach, t. VIII, s.70,80; W. Przyborowski, Dzieje 1863 r., t.II, s.207,213; S. Gesket, Voennyje dieistvija, s.319-320; S. Zieliński, Bitwy, s.228, 436; W. Karbowski, Zygmunt Padlewski, Warszawa 1969, s.344; R. Juszkiewicz, Powstanie styczniowe na Pótnocnym Mazowszu, Warszawa 1992, s.38; Urzędowy wykaz, s.316;,,Wiadomości z pola bitwy” 1863, nr 6,7, 10 z 10 V; „,Czas” 1863, nr 62, 64, 75; ,Dziennik Poznański” 1863, J. Sawicki-Stella, Ludzie i wypadki z 1861-1865 r., Lwów 1894, t.I, s.78; L. Nałęcz-Przetocki, Walki pod Wilkoszewskim i Padlewskim w:W 40 rocznicę,Lwów 1903, s.356; Z. Chądzyński, Pamiętnik, s.112, 137, 140, 194.

67 N.Berg, Zapiski o polskich powstaniach,.t.VII, s.84-85; R. Juszkiewicz, Powstanie styczniowe na pótnocnym Mazowszu, s.53.

68 S. Zieliński, Bitwy, s.237; Urzędowy wykaz, s.317.

69 S. Zieliński, Bitwy, s.239-240; Z. Grot, Rok 1863 w zaborze pruskim. Udziat spoleczeństwa w powstaniu styczniowym, Poznań 1963, s.144; R. Myśliborski-Wołowski, Udziat Prus Zachodnich w powstaniu styczniowym, Warszawa 1969, s.158,159; R. Juszkiewicz, Powstanie styczniowe na Pótnocnym Mazowszu,s.68; Urzędowy wykaz, s.317; „Niepodległość” 1863, nr 3; „Czas” 1863, nr 167, 172; Z. Chądzyński, Pamiętnik, s. 83. 
woj. krakowskiego z partią zbrojną Józefa Oksińskiego przebiegała szybko, mimo braku żywności i złych warunków atmosferycznych. Spotkanie 317 insurgentów (strzelcy, kosynierzy, kawaleria) z napotkaną rotą piechoty i oddziałem konnym zakończyło się po odrzuceniu jazdy i zagrożeniu oskrzydleniem, wyparciem Rosjan na bagnety z wioski (22 IV 1863, Golczewice) ${ }^{70}$. Wyczerpani, nienadążający za tempem marszu podwładni rozpoczęli dezercję i narzekania, gdy niepotrzebnie nadłożono drogi (wieści o konwoju polskich jeńców, pomysł zniszczenia linii kolejowej). Wybór miejsca na niezbędny odpoczynek można ocenić pozytywnie, choć szyk bojowy przeciw kilka razy liczniejszej kolumnie nieprzyjacielskiej płk. Alenicza (3 roty piesze) załamał się wskutek ucieczki lewoskrzydłowej kompanii, mimo szturmu kosynierów (24 IV, Jaworznik) ${ }^{71}$. Mossakowski stracił głowę, opuszczając plac boju, a uczestnicy ekspedycji zawrócili do Galicji

\section{Dowódcy trudni do oceny}

„Genueńczyk” Józef Tłuchowski, ps. Borowy, naczelnik jazdy w rejonie Płocka nie zdążył zademonstrować umiejętności dowódczych, gdyż sformowany przezeń 120-konny oddział został natychmiast rozproszony przez nieprzyjaciela (13 VI 1863, Kowalewo) ${ }^{72}$.

Leopold Czapiński, inteligent z Podlasia, stał u boku Aleksandra Szaniawskiego podczas bezkrwawego napadu 250 sprzysiężonych na szwadron ułanów pułku smoleńskiego, wypędzonych z miejsca stacjonowania podczas Nocy Styczniowej (22/23 I 1863, Łomazy) ${ }^{73}$. Później był oficerem w innych partiach powstańczych.

W przypadku Faustyna Grylińskiego oraz Roberta Skowrońskiego, poza doświadczeniem z armii austriackiej obydwaj szczycili się uzupełniającym kursem emigracyjnej placówki w Cuneo. Militarne predyspozycje obydwu, raczej dyskredytujące niż wyróżniające z przeciętności zostały szerzej omówione w innym miejscu. ${ }^{74}$

\section{Podsumowanie}

Przeanalizowana została dowódcza kariera ok. 5 \% insurekcyjnych komendantów, których merytoryczne przygotowanie ograniczało się do kilkumiesięcznego, emigracyjnego przeszkolenia. Cztery osoby uznać należy za wybitnych dowódców na skalę ogólnopowstańczą (Rogiński, Oksiński, Cieszkowski, Wysłouch). Kolejni trzej (Littich, Broniewski, Kołyszko, Suzin) zaliczeni być powinni do kategorii rozwijających się stopniowo, obiecujących naczelników. Jako przeciętnego, niewyrastającego ponad insurekcyjną średnią uznać trzeba jednego (Jabłonowski), natomiast do niekompetentnych dowódców niewątpliwie kwalifikowali się również dwaj (Jurkowski, Mossakowski). Doliczając jednoczesnych oficerów austriackich

70 W. Przyborowski, Dzieje 1863 r., t.IV, s.217, 290; S. Zieliński, Bitwy, s.167; „Wiadomości z pola bitwy” 1863, nr 10 z 7 V; „Czas” 1863, nr 92, 94, 96, 97; Gazeta Narodowa nr 52, 66; S. Wierzbiński,Opisanie wojennych wypraw, w których bratem udziat, w: A.Giller, Polska w walce, s.171, 184, 185; C.Pieniążek, Lat temu 27. Kartki z pamiętnika, Kraków 1890, s.81-88; E. Klebert, Wyprawa Mossakowskiego w: W 40 rocznice, s.194.

71 S. Zieliński, Bitwy, s.167-168; E. Kozłowski, Wyprawy wojenne, s.126; Urzędowy wykaz, s.294; pozostałe dane bibliograficzne jak przyp.52.

72 S. Zieliński, Bitwy, s.237; „Czas” 1863, nr 159.

73 N. Berg, Zapiski o polskich powstaniach; W. Przyborowski, Dzieje, t.I, s.101; S. Zieliński, Bitwy, s.57; J. Tomczyk, Organizacja cywilno-wojskowa powstania styczniowego, s.39; S. Góra, Partyzantka, s.63, 65.

${ }_{74}$ Ze względu na fakt, że to raczej proweniencja z sił zbrojnych państwa zaborczego w decydującym stopniu ważyła na przygotowaniu do funkcji pełnionych podczas zrywu narodowowyzwoleńczego. Zob. A.Buława, Byli oficerowie armii austriackiej jako dowódcy powstańczych oddziałów zbrojnych (1863-1864) w: Gloria victis 1863 r., Studia i szkice z dziejów Powstania Styczniowego, red. T.Matuszak, Warszawa-Piotrków Trybunalski, s.57-60. 
(Gryliński, Skowroński), otrzymamy reprezentację czteroosobową. Dwie sylwetki dowódcze potraktowano jako trudne do zobiektywizowanej oceny (Tłuchowski, Czapiński).

Około połowy omawianej grupy wykazało sprawność, jeśli nie biegłość w roli naczelników nieregularnych jednostek zbrojnych. Reszta nie spełniła oczekiwań, albo trudno poddać ją wyważonemu wartościowaniu. Jak w większości pozostałych grup proweniencyjnych, decydujące pozostawało usposobienie każdego z osobna. W innym razie kilkumiesięczne przeszkolenie nie spełniłoby zadania. Obydwaj dowódcy, posiadający w życiorysie oprócz włoskiego kursu emigracyjnego epizod w armii austriackiej, nie stanęli na wysokości zadania, choć ich potencjał w omawianym zakresie powinien być ponadprzeciętnie wysoki.

Wypada zgodzić się z Janem Molińskim, przekonanym, iż przede wszystkim kompetentna kadra wykładowcza miała niezaprzeczalny wpływ na to, że krótkotrwałe, acz intensywne szkolenie mogło być wystarczające dla przyswojenia ogólnych zasad walki i dowodzenia małymi oddziałami. Mimo że kurs poświęcony był teorii regularnych zmagań zbrojnych, pozyskana wiedza umożliwiła później uzdolnionym słuchaczom adekwatny wybór metod działania oddziałów partyzanckich ${ }^{75}$.

\section{Theory and practice. Verification commander skills graduates of Polish Military School in Genoa and Cuneo (1861-1862) during the January Uprising (1863-1864) Summary}

In the run-up to independence uprising, from October 1861 to June 1862 thanks to permit the authorities of the United Kingdom of Italy and the intervention of Giuseppe Garibaldi functioned in Genoa and Cuneo Polish Military School was closed due to diplomatic pressure by the partitioning powers. Over the course of several months was the theoretical preparation of the January Uprising leadership cadre, and 15 graduates covered the self-command of the guerrilla armed parties. 4 of them belonged to the most prominent commanders for the entire war, also 4 can be regarded as promising. One showed just to be average, two were clearly weak. In two cases, it is difficult to set a clear assessment. For two commanders, former soldiers of the Austrian army were disappointing in the field. The Italic episode was an added element of military knowledge. The most significant was the individual's characteristics, although it certainly proved to be a useful body of knowledge transmitted by the emigration of well-prepared teachers cadet school.

Keywords: Polish Military School in Italy, Genoa, Cuneo, January Uprising commanders, theoretical preparation, commanding skills assessment in practice

Nota o Autorze: dr Adam Bulawa, ur. 1971, adiunkt na Wydziale Nauk Historycznych i Społecznych UKSW -Zakład Historii Wojskowości przy Katedrze Historii XIX i XX wieku Instytutu Nauk Historycznych. Zainteresowania naukowe: historia Polski i powszechna XIX i XX w., historia wojskowości.

75 J.Moliński, Przygotowania do wybuchu powstania styczniowego, s.97. 